\title{
Ovulation rate, litter size and prenatal losses in hair sheep of the French West Indies
}

\author{
Maurice MAHIEU ${ }^{\mathrm{a} *}$, Yves CogniÉ ${ }^{\mathrm{b}}$, Philippe CHEMINEAU $^{\mathrm{b}}$ \\ ${ }^{a}$ Unité de Recherches Zootechniques, INRA-Antilles-Guyane, Prise d'eau, 97170 Petit-Bourg, \\ Guadeloupe, France \\ b Physiologie de la Reproduction et des Comportements, UMR 6073 INRA-CNRS-Université de Tours, \\ 37380 Nouzilly, France
}

(Received 3 September 2003; accepted 19 March 2004)

\begin{abstract}
Ovulation rate (OR) and litter size (LS) were recorded in local hair sheep of Martinique and in local $\times$ Lacaune-viande crossbreeds, in order to assess prenatal losses. Local hair sheep LS and $\mathrm{OR}$ were 1.91 and 2.41, respectively. Prenatal losses increased with $\mathrm{OR}$, from $0.22(\mathrm{OR}=2)$ up to $1.50(\mathrm{OR}>3)$. The ewes $(69.7 \%)$ with $\mathrm{LS}=1$ had actually lost at least one ovum, against $25.9 \%$ of the ewes with LS $>1$. Ewes grazing Cynodon nlemfuensis (Stargrass) had lower LS than those grazing Digitaria decumbens (Pangola), in relation with a lower nutritional level and, maybe, more parasitism effects. No seasonal or age at lambing effect was shown. The OR and LS were dramatically decreased on local $\times$ Lacaune-viande crossbred ewes (minus 1.32 and 0.67 unit, respectively, $P<$ 0.05 ). This suggests a possible negative effect of the tropical environment on the crossbreeds' reproductive function.
\end{abstract}

ovulation rate / litter size / prenatal losses / humid tropics / hair sheep / Lacaune-viande / crossbreeding

\section{INTRODUCTION}

In the Caribbean Islands, local hair sheep populations (e.g. the Barbados Black-belly, the Virgin Islands White or St Croix, the West African or Pelibuey [1-3]) are known to be prolific and to breed continuously [4]. Crossbreeding with meat breeds from temperate countries is often done in these islands to enhance growth rate and carcass conformation. Crossbred ewes are sometimes kept for replacement, though there is no factual information on their reproductive abilities.

A twenty-year study was done in Martinique to assess different aspects of the responsiveness of local hair sheep reared under an irrigated grazing system, based on Pangola grass (Digitaria decumbens). This system was designed to increase animal as well as acreage productivity in farm-like management conditions, without any concentrate feed supply. The main result was a yearly weaned lamb production ranging from 1090 to $1250 \mathrm{~kg}$ live weight per hectare, which is one of the highest sheep acreage production rates ever described. Such a result was due to a high stocking rate and growth rate, as well as to reproductive performances [5]. The ovulation rate (OR) of local hair sheep was measured in a previous experiment [4], using maiden ewes kept out of reproduction from 6 to 18 months of age.

* Corresponding author: mahieu@antilles.inra.fr 
Their mean OR ranged from 2.2 to 2.3 , when the mean litter size (LS) of the flock they were born into was 1.6 to 1.8 , suggesting that an average of about 0.5 to 0.6 ova, embryo or foetus per pregnant ewe was lost either by fertilisation failure or by embryo or foetus death [5]. The causes and time of wastage were reviewed by several authors, like Bodin et al. [6] or Michels et al. [7], concerning wool breeds. Several factors are known to act on fertilisation or embryo survival, among them nutritional and genetic factors $[8,9]$. Very few publications concerning hair sheep are available [10], and most of them were obtained in temperate countries (USA) [11, 12].

This paper presents data on the individual relationship between ovulation rate, litter size and prenatal losses in the local hair sheep of Martinique (FWI), and some preliminary results indicative of the consequences of grazed forage species and crossbreeding on these reproductive traits.

\section{MATERIALS AND METHODS}

\subsection{Location}

Information on ovulation rate and lambing data were collected over a 1 year period for an ewe flock raised on irrigated pastures located at the SECI (Conseil Général de la Martinique), in Martinique $\left(14.25^{\circ} \mathrm{N}, 60.50^{\circ}\right.$ $\mathrm{W})$. The annual rainfall was about $1500 \mathrm{~mm}$, with a marked dry season from January to July. Average air temperature varied from $25.3^{\circ} \mathrm{C}$ (January) to $27.7^{\circ} \mathrm{C}$ (July), relative humidity (hair hygrometer) was always above $55 \%$ and day length ranged from 11-13 $\mathrm{h}$.

\subsection{Animals and management}

Ninety-six (from 1 to 8-year old) local hair sheep ewes and twenty-seven F1 (from 1 to 2-year old) crossbred maiden ewes - from the same Lacaune-viande sire - were monitored. The ewe lambs were at least 7 months old and weighed at least $27 \mathrm{~kg}(60 \%$ of the mature ewe weight) when mated. Three 35day mating periods were done in December 1986, April and August 1987, each one concerning half the flock, in order to achieve an 8-month lambing interval. The maximum ewes: ram ratio was 35 to $45: 1$, whatever the period. Five rams belonging to the local population were used. No hormonal synchronisation was done during the experiment.

The flock was divided into two groups, the first one ( $n=66$ hair sheep and $21 \mathrm{~F} 1)$ grazing a Digitaria decumbens (Pangola) and the second ( $n=30$ hair sheep and $6 \mathrm{~F} 1)$ a Cynodon nlemfuensis (Stargrass) pasture. The two pastures were irrigated during the dry season and received yearly one ton of a 27-9-18 fertiliser per ha (the available daily leaves dry matter was over $1 \mathrm{~kg}$ per ewe, for the two groups). The animals were drenched bimonthly for gastro-intestinal nematodes (mainly Haemonchus contortus and Trichostrongylus colubriformis) and dipped fortnightly against ticks (Amblyomma variegatum) and tick-borne diseases (dermatophilosis). No supplement was supplied except mineral licks.

\subsection{Measurements and data analyses}

The ovulation rate (OR) was assessed by laparoscopy [4], during the first week following the end of each mating period. OR data (162) (125 for hair sheep + 37 for F1) were recorded and analysed. Left and right ovary counts were done separately, and the ovulation was defined as asymmetrical if the difference between the two values was greater or equal to 2 ova.

The percentage of ovulating ewes (ewes showing corpora lutea by mated ewes) was calculated from the OR data. The Litter Size (LS), defined as the number of lambs born (dead or alive) per lambing ewe, and the apparent fertility (AF), were calculated from the lambing data records. Ovulating ewes without lambing were presumed as non-fertilised, and all the ova of lambing ewes were considered as fertilised [13], although this 
"all-or-none" hypothesis was probably oversimplified [14]. The prenatal losses (PL) were defined as the individual difference between OR and LS. OR was computed on the basis of ovulating ewes, LS and PL on the basis of lambing ewes. Only one ewe produced 5 ova, so its data were pooled with those of ewes producing 4 ova.

The 35 ovulation data from F1 maiden ewes were compared only to the 31 data from local maiden ewes born during the same year, to avoid any bias linked to an age effect. The lambs were weighed within one day after birth.

The analyses were done using the NPAR1WAY procedure (SAS v. 6.12 [15]) as OR and related data did not follow a Gaussian distribution. The pasture, season, age of ewes at lambing, and sire (for LS and PL), and the asymmetry between ovaries and day of lambing - as an estimate of the pregnancy stage when laparoscopy was done - (for PL) were taken into account in the models for comparing hair sheep. Due to an unbalanced design and small number of F1 ewes, they were not taken into account in the pasture effects analyses. The breed effect was only taken into account in the comparison of hair sheep vs. Lacaune crossbreeds. Lamb birth weight analysis was done using the GLM procedure (SAS v. 6.12 [15]). The PL within LS, pasture, season, age of ewes at lambing and sire were taken into account in this model. Birth weight least squares means are given with standard errors. Percentage frequencies are given with a 95\% confidence interval.

\section{RESULTS}

The percentage of ovulating hair sheep ewes was $100 \%$ for the three mating periods. The apparent fertility was $93.6 \%$ and the mean litter size was $1.91(\mathrm{sd}=0.80)$. The litters $(28.0 \%)$ [confidence interval 0.95: 21 $40 \%$ ] were single lambs, $53.4 \%$ [40-60\%] twins, and $18.6 \%$ [13-29\%] triplets or more. The mean Ovulation Rate was 2.41
( $\mathrm{sd}=0.82)$ ova per ovulating ewe. Ten ewes out of 118 [4-17\%] were mono-ovulating, 97 [71-87\%] produced two or three ova, and 11 [4-17\%] produced four ova or more.

The relationship between OR and LS is given in Table I. The LS increased with OR from 1 to 3 ova and more. The Prenatal Losses were 0.22 when OR was equal to 2 ova, and increased linearly to 1.50 when OR was more than 3 ova ( 0.64 ova lost per OR unit). The analysis of LS in relation with OR indicated that $69.7 \%$ of ewes birthing a single lamb had lost at least one ovum, when only $25.9 \%$ of ewes birthing twin lambs or more had lost ova. No effect of asymmetry between the left and right ovaries was found on PL. The slight birth weight decrease for lambs from dams losing ova was not significant (Tab. II), even though the results showed otherwise $(P=0.065$ for $\mathrm{LS}=1)$. In this study, there was no seasonal effect on the percentage of ovulating ewes and apparent fertility, and no significant effect of season, or age at lambing on OR, LS and PL. No sire effect was shown on LS or PL. No day of lambing effect was shown on PL.

\section{Pasture and crossbreeding effects}

The apparent fertility was $94.1 \%$ and $91.7 \%$ for the ewes grazing on Pangola and Stargrass, respectively $(P=0.62)$. The ewes grazing on Pangola showed higher LS than those grazing on Stargrass (2.00 vs. 1.61, $P<0.01$, respectively). The OR difference was not significant (2.48 vs. 2.22, $P=0.07$, respectively). The PL ( 0.52 vs. 0.55 for Pangola and Stargrass, respectively) was not significantly different for the two groups $(P=0.87)$. The lamb birth weights were not significantly different for the two groups ( $2.80 \pm 0.10$ vs. $2.71 \pm 0.12$, for Pangola and Stargrass, respectively, $P=0.28$ )

Two of the youngest F1 maiden lambs (7-mo old) did not ovulate in December, one showing no ovarian activity at all, the other one only some follicles. The OR was 1.23 vs. 2.55 , and LS 1.13 vs. 1.80 , for the F1 and local ewes, respectively, and these 
Table I. Litter size, prenatal losses, and litter size to ovulation rate ratio in hair sheep of Martinique, according to the ovulation rate.

\begin{tabular}{lcccccc}
\hline & \multicolumn{2}{c}{ No-lambing ewes } & & \multicolumn{4}{c}{ Lambing ewes } \\
\cline { 2 - 5 } \cline { 5 - 7 } Ovulation Rate & \# data & & \# data & Litter Size & Prenatal Losses & LS/OR \\
\hline 1 & 2 & & 10 & $1.00^{\mathrm{a}}$ & - & - \\
2 & 2 & & 60 & $1.78^{\mathrm{b}}$ & $0.22^{\mathrm{a}}$ & 0.89 \\
3 & 2 & & 37 & $2.14^{\mathrm{c}}$ & $0.86^{\mathrm{b}}$ & 0.73 \\
$>3$ & 1 & & 11 & $2.55^{\mathrm{c}}$ & $1.50^{\mathrm{c}}$ & 0.62 \\
All & 7 & & 118 & 1.91 & 0.51 & - \\
\hline
\end{tabular}

a,b,c Data within a column followed by different subscript letters differ significantly $(P<0.01)$.

Table II. Birth weight of lambs (kg) from dams losing ova or not, in hair sheep of Martinique, according to the litter size.

\begin{tabular}{lcccccc}
\hline & \multicolumn{2}{c}{ No ova loss } & & \multicolumn{2}{c}{ Ova loss } & \\
\cline { 2 - 3 } \cline { 5 - 7 } Litter Size & \# lambs & Birth weight & & \# lambs & Birth weight & $P\left(\mathrm{H}_{0}\right)^{*}$ \\
\hline 1 & 10 & $3.89 \pm 0.16$ & & 23 & $3.54 \pm 0.11$ & 0.065 \\
2 & 84 & $2.90 \pm 0.06$ & & 34 & $2.85 \pm 0.09$ & 0.620 \\
$>2$ & 45 & $2.50 \pm 0.08$ & & 18 & $2.34 \pm 0.13$ & 0.270 \\
\hline
\end{tabular}

$* \mathrm{H}_{0}$ : null hypothesis.

differences were highly significant. Due to the small number of multi-ovulating crossbred ewes, no comparison was done for the prenatal loss. The apparent fertility of $\mathrm{F} 1$ was $91 \%$, for animals showing ovarian activity, and $97 \%$ for local hair sheep, but the difference was not significant $(P=0.37)$.

\section{DISCUSSION}

The apparent fertility and litter size were consistent with those recorded for other years on the same flock, and reared under the same conditions [5]. The ovulation rate was also similar to OR recorded on the same location on non-mated hair sheep: 2.2 and 2.3 [4]. It was slightly higher than those recorded on Barbados Black-belly ewes: 1.86 to 2.04 [11].

The available data set showed no seasonal effect on the percentage of ovulating ewes, and no significant variation in the OR between the seasons or the age at lambing. The latter is consistent with the results of Rojas and Rodriguez, reporting no age effect on Barbados Black-belly ewes OR [16]. Neither the seasons, age or sire affected the LS or PL. However, such results may be due to a sampling effect: over a 20-year study on the reproductive performances of the flock (more than 1300 lambing data), including the data of this study, the increase of LS up to the 3rd lambing at least [17] showed an effect of age until full maturity, which may be due to either the ovulation rate or the prenatal losses. This age effect was also supported by Schoenian and Burfening [18], comparing low and high prolificacy lines in Merino, or by Michels et al. [7] reviewing the ewe-embryo relationship.

The LS increased with OR from 1 to 3 ova and more, while Scaramuzzi and Downing [19] indicated a maximum $L S$ when $O R=3$, and a decrease over 3 ova, for Merino and Merino $\times$ Border Leicester ewes. On the 
contrary, Davis et al. [20] showed that the LS increases with OR until 4, for Romney, Coopworth and Perendale sheep in NewZealand, with the proportion of embryos retained being $0.89,0.77$ and 0.64 respectively, for ovulation rates two, three and four. Our results of LS/OR appeared very similar (Tab. I). The PL was low when OR =2, but increased significantly over 2 ova, according to the results published by Ricordeau et al. [21].

Scaramuzzi and Downing [19] found that the risk of implantation failure increases slightly, due to transuterine migration. However, no relationship was found between asymmetry in the number of ova shed and prenatal losses, since the data set was not large enough to allow confirmation of the hypothesis. Partial fertilisation, no implantation, or very early death of the foetus, were suggested by the lack of prenatal loss effect on birth weight, as previously reported in the literature $[6,7,22]$.

The results of the Pangola vs. Stargrass comparison suggested a possible effect of nutrition level $[8,9,23]$, or a combined effect of nutrition and parasitism, in relation to the differences of structure and microclimate between the two pastures. These hypotheses are supported by the results of a 5-year Pangola vs. Stargrass comparison, including the studied animals. The ewes' live weight difference (minus $1.25 \mathrm{~kg}$ for the Stargrass vs. Pangola, $P<0.001$ ), the poorer milk production of the ewes and growing performances of the lambs for the Stargrass [5] indicated a lower nutrition level. Moreover, the growth rate was more affected for male lambs than for ewe lambs, suggesting a higher parasitism effect for the Stargrass flock [24], which could also act on the ewe reproductive efficiency. However, the present experiment was not conclusive on this point, due to a lack of parasitism data.

The crossbreeds' OR and LS were significantly decreased as opposed to local hair sheep and this decrease can be estimated to 1.32 ova and 0.67 lamb per ewe. This was quite unexpected, since the litter size of Lacaune-viande ewes, as published by the "Bureau des Ressources Génétiques" [25], was an estimated 1.77 in France, and roughly the same LS was found for the local ewes in Martinique. It can be suggested that their ovulation rate was also roughly around 2 or more. The expected crossbreeds' LS could be an estimated $1.84((1.77+1.91) / 2)$, and crossbreeds' OR could also be estimated over 2. In the worst hypothesis of this Lacaune sire transmitting only a mono-ovulation trait, the expected F1 OR and LS would be 1.70 $((2.41+1) / 2)$ and $1.45((1.91+1) / 2)$, respectively. Although a sire effect could be confused with the breed effect, this result points out the possibility of a strong negative heterosis in the humid tropic conditions, maybe linked to nutritional, parasitic as well as climatic effects. This seems very different from the results of crossbreeding between more closely related breeds, like the Berrichon du Cher and Romanov in France [21], or like D'Man (high-prolificacy) and Sardi (lowprolificacy) in Morocco which showed only a very slight (minus $0.5 \%$ ) negative heterosis for OR [26]. Our results were also very different from those of crossbreeding experiments in the USA (Illinois Univ.), using crossbred ewe lambs from Targhee or Suffolk dams sired by hair sheep rams (Barbados Blackbelly and St Croix). The F1 ewe lamb prolificacies were 1.38 and 1.58 [12], whereas the dam breed prolificacies were 1.16 and 1.22 [27], and the purebred St Croix and Blackbelly prolificacy ranged from 1.44 1.89 as reviewed by Wildeus [28].

\section{CONCLUSION}

The OR and PL performances of the Martinique local hair sheep take place within the prolific breeds. The ova or embryo losses increase with the ovulation rate, as in other prolific breeds, and no evidence of late abortion was shown.

Although these results were obtained in farm-like conditions, and cannot be fully conclusive, two points of interest can be pointed out and could warrant further experiments. 
The first concerns the assessment of crossbreeding effects on reproduction when the exotic breed is poorly adapted to the environmental conditions. The second one could be designed to assess the effect of the parasitism level on the reproductive performances.

\section{ACKNOWLEDGEMENTS}

To Ms Natasha Greene and Ms. Natasha Callender, Drs L. Bodin and A. Menéndez Buxadera, for their kind help and suggestions, and gratefully to the SECI's technical team. To the farmers' co-operative SCACOM, which were funded by the FEOGA to import the Lacauneviande purebred sheep, and to the "Conseil Général de la Martinique", which supported this work. To the reviewers, for their constructive criticism.

\section{REFERENCES}

[1] Bastien O, Matheron G, Leimbacher F. Le mouton en Martinique. I. Description des principaux phénotypes identifiés et étude de quelques caractères morphologiques. Comptes rendus - $1^{\text {res }}$ Journées de la Recherche Ovine et Caprine aux Antilles-Guyane, 9-10 Octobre 1988. Rev Elev Méd Vét Pays Trop 1991, $\mathrm{n}^{\circ}$ spécial: $75-82$.

[2] Mason IL. Prolific tropical sheep. FAO Animal Production and Health Paper 17, 1980, $124 \mathrm{p}$.

[3] Naves M, Alexandre G, Leimbacher F, Mandonnet N, Menendez-Buxadera A. Les ruminants domestiques de la Caraïbe : le point sur les ressources génétiques et leur exploitation. Prod Anim, INRA 2001, 14: 181-192.

[4] Mahieu M, Jego Y, Driancourt MA, Chemineau P. Reproductive performances of Creole and Black-Belly ewes in the West Indies. A new major gene controlling ovulation rate. Anim Reprod Sci 1989, 19: 235-243.

[5] Mahieu M, Aumont G, Alexandre G. Intensive management of tropical hair sheep in Martinique. Prod Anim (Paris) 1997, 10: 2132 (in French).

[6] Bodin L, Hanrahan JP, Poivey JP. Variation in embryo survival in sheep and goats. 43rd Annual Meeting of the EAAP, 14-17 September 1992, Madrid, 1992, 23 p.
[7] Michels H, Vanmontfort D, Dewil E, Decuypere E. Early prenatal survival in relation to the parental environment in sheep: A review. Small Rumin Res 1998, 29: 143-156.

[8] Downing JA, Scaramuzzi RJ. Nutrient effects on ovulation rate, ovarian function and the secretion of gonadotrophic and metabolic hormones in sheep. J Reprod Fertil Suppl 1991, 43: 209-227.

[9] Smith JF, Rattray PV, Jagusch KT. Nutritional manipulation of reproduction. Proceedings of the World Congress on Sheep and Beef Cattle Breeding. Vol I. The Dunsmore Press Limited, Palmerston North, New Zealand, 1982, p 375-385.

[10] Cruz Lazo C, Fernandez Baca S, Alvarez Leon JA, Perez Ramirez H. Seasonal variations in ovulation, fertilization and embryo survival in Tabasco ewes in the humid tropics. Veterinaria Mexico 1994, 25: 23-27.

[11] Bradford GE, Quirke JF. Ovulation rate and litter size of Barbados, Targhee and crossbred ewes. J Anim Sci 1986, 62: 905-909.

[12] Bunge R, Thomas DL, Nash TG. Performance of hair breeds and prolific wool breeds of sheep in southern Illinois: lamb production of F1 ewe lambs. J Anim Sci 1993, 71: 20122017.

[13] Restall BJ, Brown GH, Blockey MA, Cahill L, Kearins R. Assessment of reproductive wastage in sheep. 1. Fertilization failure and early embryonic survival. Aust J Exp Agric Anim Husb 1976, 16: 329-335.

[14] Michels H, Vanmontfort D, Dewil E, Decuypere E. Genetic variation of prenatal survival in relation to ovulation rate in sheep: A review. Small Rumin Res 1998, 29: 129-142.

[15] SAS Institute Inc., Cary NC, SAS version 6.12, 1996.

[16] Rojas-Rodriguez O, Rodriguez-Rivera OL. Ovulation rate and presence of follicles after oestrus in Barbados Blackbelly ewes. Tecnica Pecuaria en Mexico 1997, 35: 32-38 (in Spanish).

[17] Mahieu M, Aumont G, Menendez-Buxadera A, Chemineau P, Alexandre G. Productividad y duración de la vida del ovino tropical criados en pastos irrigados de la Martinica. XVII Reunión de la Asociación Latinoamericana de Producción Animal, La Habana, Cuba, 20-23 de noviembre 2001, p 497-500.

[18] Schoenian SG, Burfening PJ. Ovulation rate, lambing rate, litter size and embryo survival of Rambouillet sheep selected for high and 
low reproductive rate. J Anim Sci 1990, 68: 2263-2270.

[19] Scaramuzzi RJ, Downing JA. The distribution of ovulations from the ovaries of Merino and Border Leicester $\times$ Merino ewes and its effect on the survival of their embryos. Anim Reprod Sci 1997, 47: 327-336.

[20] Davis GH, Morris CA, Dodds KG. Genetic studies of prolificacy in New Zealand sheep. Anim Sci 1998, 67: 289-297.

[21] Ricordeau G, Razungles J, Eychenne F, Tchamitchian L. Reproductive performance of Cher Berrichon, Romanov and crossbred ewes. II. Components of prolificacy. Ann Génet Sélect Anim 1976, 8: 25-35 (in French).

[22] Dingwall WS, Robinson JJ, Aitken RP, Fraser C. Studies on reproduction in prolific ewes. 9. Embryo survival, early foetal growth and within-litter variation in foetal size. J Agric Sci UK 1987, 108: 311-319.

[23] Gunn RG, Doney JM. The interaction of nutrition and body condition at mating on ovulation rate and early embryo mortality in Scot- tish Blackface ewes. J Agric Sci UK 1975, 85 465-470.

[24] Yazwinski TA, Goode L, Moncol DJ, Morgan GW, Linnerud AC. Haemonchus contortus resistance in straightbred and crossbred $\mathrm{Bar}$ bados Blackbelly sheep. J Anim Sci 1980, 51: 279-284.

[25] http://www.brg.prd.fr/brg/ecrans/rgaBd_ovins.htm, Bureau des Ressources Génétiques, 2001.

[26] Boujenane I, Chafik A, Bradford GE, Berger YM. Litter size and its components in D'man, Sardi and D'man $\times$ Sardi ewes. Proceedings, 3rd World Congress on Sheep and Beef Cattle Breeding, Vol 2. Institut National de la Recherche Agronomique, Paris, France, 1988, p 657660 (in French).

[27] Laster DB, Glimp HA, Dickerson GE. Factors affecting reproduction in ewe lambs. J Anim Sci 1972, 35: 79-83.

[28] Wildeus S. Hair sheep genetic resources and their contribution to diversified small ruminant production in the USA. J Anim Sci 1997, 75: 630-640. 